\title{
Dermoscopic and reflectance confocal microscopic findings in a case of plasma-cell cheilitis
}

\author{
Bir plazma hücreli keilit olgusunda dermoskopik ve reflektans konfokal \\ mikroskopik bulgular
}

๑ Banu Yaman, ๑ Ișıl Karaarslan*, ๑ Ayda Acar*, ๑ Mine Hekimgil, ๑ Taner Akalın, ๑ Fezal Özdemir*

Ege University Faculty of Medicine, Department of Pathology; *Department of Dermatology, Izmir, Turkey

Keywords: Plasma-cell cheilitis, reflectance confocal microscopy, dermoscopy

Anahtar Kelimeler: Plazma hücreli keilit, reflektans konfokal mikroskopi, dermoskopi

\section{Introduction}

Plasma-cell cheilitis (PCC) is an idiopathic benign inflammatory condition which is commonly seen in elderly people and considered as a low category plasma cell mucositis ${ }^{1}$. It is a rare disease with less than 50 cases reported in the literature ${ }^{2,3}$. It is generally seen as a flat to slightly raised, erythematous patch or plaque lesion on the lower lip. There may be erosion, ulcers, bleeding or crust ${ }^{4,5}$. Many benign and malignant conditions may be considered in the differential diagnosis of PCC, especially actinic cheilitis (AC) and early squamous cell carcinoma (SCC).

Dermoscopy and reflectance confocal microscopy (RCM) are well known in vivo diagnostic techniques which have been proven to be useful in the diagnosis of skin lesions. However, there has been only one report describing the dermoscopic features of PCC in the literature ${ }^{4}$. On the other hand, to our knowledge, the RCM features of PCC have not been described previously.

\section{Case Report}

An 85-year-old male patient referred to our clinic with a prediagnosis of SCC of the lower lip. The patient was complaining of tenderness and crusting of his lip for the last few years. On clinical examination there was a widespread erythematous patch with erosions and some tiny ulcerations and a yellow crust on the lower lip (Figure 1). Total body examination was normal and the blood tests were all within normal limits.

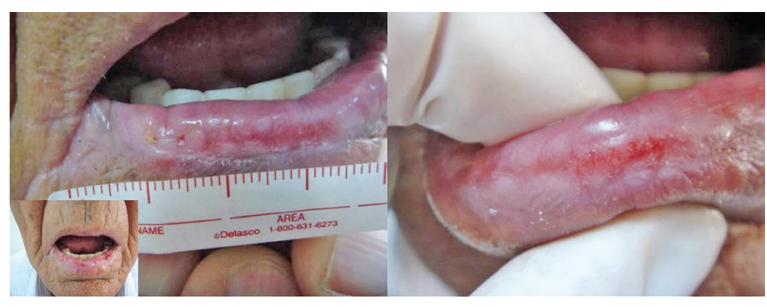

Figure 1. Erythematous patch with erosions and some tiny ulcerations at the lower lip

Yazışma Adresi/Address for Correspondence: Ayda Acar MD, Ege University Faculty of Medicine, Department of Dermatology, İzmir, Turkey Tel.: +90 2323902698 E-posta: aydaerbas@yahoo.com Geliş Tarihi/Received: 04.09.2020 Kabul Tarihi/Accepted: 29.11.2020 ORCID: orcid.org/0000-0001-7507-6999 
Dermoscopic examination revealed a polymorphous vascular pattern with widespread dotted vessels, and some glomerular and linearirregular ones on a whitish-reddish background, and ulceration (Figure 2).

On RCM, a regular honeycomb pattern which was elongated in some areas was observed at the epidermal level. There were many dendritic and inflammatory cells in the epidermis but no atypical cell was observed. Dermoepidermal junction was visible in some areas. In the upper dermal level, there were some monomorphic, moderately refractive diffuse infiltration of medium/large sized roundish cells together with some bright inflammatory cells (Figure 3).

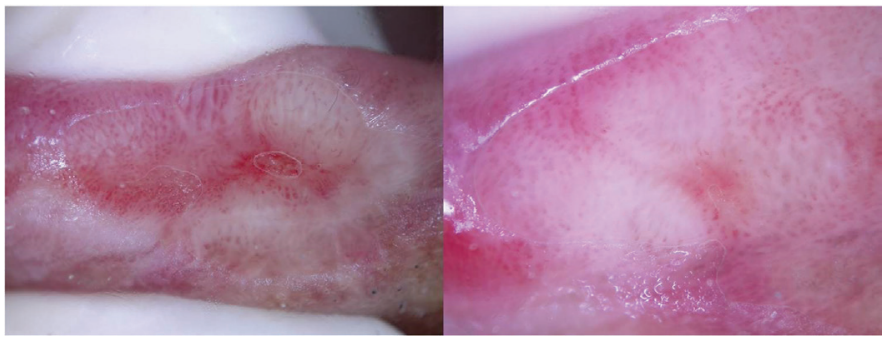

Figure 2. Dermoscopically widespread dotted vessels with some glomerular and linear-irregular ones on a whitish-reddish background and ulceration
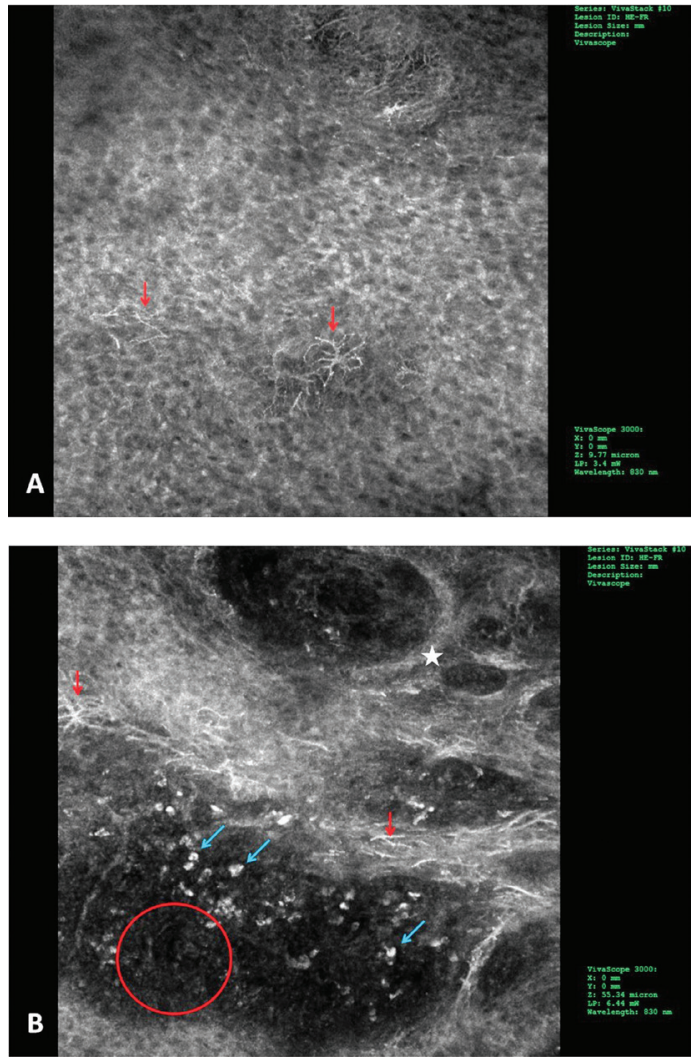

Figure 3. (A) Regular honeycomb pattern and dendritic extensions (red arrows) on the RCM image at the epidermal level. (B) Some dendritic cells at dermoepidermal junction (white asterisk) and monomorphic, moderately refractive diffuse infiltration of medium/ large sized roundish cells (red circle) at the upper dermal level, together with some bright inflammatory cells (blue arrows)

RCM: Reflectance confocal microscopy
Histopathologically, there was a dense, band-like infiltrate at the subepithelial region predominantly composed of plasma cells. Polymorphonuclear leukocytes, lymphocytes, and histiocytes were admixed especially around the erosion at the surface. Special stains for fungi and bacteria were negative. There was no evidence of granuloma, dysplasia or malignancy. Plasma cell infiltrate was polyclonal consisting of kappa and lambda positive cells. Kappa positive cells were two to three times more than lambda cells in the infiltrate (Figure 4). The diagnosis of PCC was made.

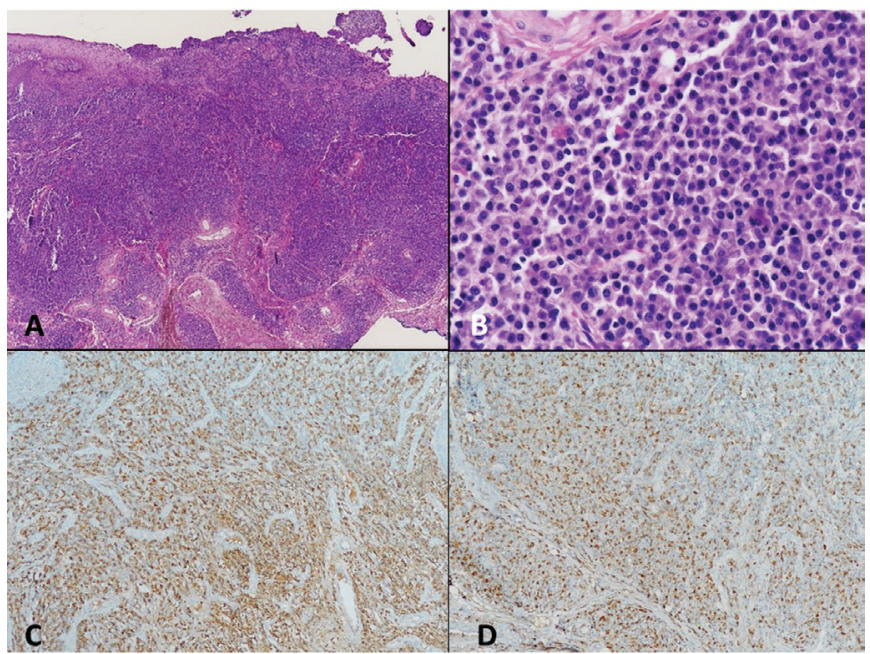

Figure 4. $(A, B)$ Histopathologically dense infiltration of plasma cells at the lamina propria [hematoxylin and eosin (H\&E), x40, x200)]; (C,D) immunohistochemical staining showed polyclonality of the dense plasma cell infiltration with kappa and lambda antibodies (H\&E, x40)

\section{Discussion}

Plasmacytosis circumorificialis or plasma cell mucositis is a rare disorder affecting different body regions such as lips, buccal mucosa, gingiva, tongue, vulva, and glans penis ${ }^{6}$. The first reported case of plasma cell mucositis was plasma cell balanitis described by Zoon in 1952. It was previously reported as plasma cell orificial mucositis, idiopathic plasmacytosis, oral papillary plasmacytosis, idiopathic plasmacytosis of the oral and supraglottic area etc. ${ }^{1,8}$

PCC is considered as a subtype of plasma cell mucositis ${ }^{1}$. It is an extremely rare disease with less than 50 cases in the literature ${ }^{2,9}$. The etiology of PCC is unknown, although chronic stimuli, solar damage, hypertension and metabolic abnormalities are regarded as etiologic factors ${ }^{6}$. It is clinically characterized by flat to slightly raised, erythematous patches or plaque lesions with relatively clear margins on the lower lip of elderly people. It may be complicated with erosion, ulceration, bleeding or crusts ${ }^{4,5}$. Solomon et al. ${ }^{1}$ presented that the mean age was 56.6 years with a male to female ration 1,2:1.

The clinical and histopathological differential diagnosis of PCC may include AC, SCC in situ, contact dermatitis, granulomatous cheilitis, syphilis, and other infectious diseases. Contact dermatitis can be ruled out clinically and with the patient's history. Syphilis and the immunological disorders can be differentiated with the findings of serological and laboratory tests. Granulomatous cheilitis can clinically 
resemble PCC; however, histopathologically, it shows evidence of a granulomatous infiltrate rather than a plasma-cell infiltrate. The clinical features together with a good anamnesis may help in the differential diagnosis, However, in vivo diagnostic techniques may be necessary to distinguish AC and early SCC.

There has been only one report describing the dermoscopic features of PCC in 2 cases $^{4}$. The dermoscopic features described in that report were radially arranged vascular enlargement and proliferation around the ulceration ${ }^{4}$. We observed polymorphous vascular structures on a whitish-reddish background and ulceration. With these findings it was not easy to exclude AC or SCC, considering the reported dermoscopic features of AC and SCC such as white structureless areas, polymorphous vessels, white circles, ulceration, and scales ${ }^{4,10-13}$. Thus, RCM evaluation would be beneficial.

RCM is a non-invasive, real-time microscopic imaging system useful for the evaluation of skin diseases. The RCM findings of AC and SCC have been described in a few reports ${ }^{10,11,14}$. The main feature of $A C$ is keratinocyte atypia at the epidermal level. In SCC, more extensive keratinocyte atypia, disarrangement of the squamous epithelium, round bright nucleated cells, and atypical nucleated cells in the superficial dermis are seen ${ }^{15}$. In our case there was no atypia at the epidermal level. In the upper dermal level monomorphic, moderately refractive diffuse infiltration of medium/large sized roundish cells together with some bright inflammatory cells were seen. In the light of these findings it was possible to rule out AC and SCC.

Histopathologically, PCC is characterized by dense mature plasmocytic infiltration at the lamina propria. The surface epithelium can be hyperplastic or atrophic whereas ulceration can also be seen. There may be some polymorphonuclear leucocytes and lymphocytes. The dense plasma cells show polyclonal phenotype with kappa and lambda light chains. The identification of polyclonal expression of plasma cells can help in the differential diagnosis of various other plasma cell disorders ${ }^{1,3}$. The biopsy of our patient revealed dense polyclonal plasma cells with kappa predominance. There was no evidence of granuloma, infectious diseases, carcinoma, or other malignant disorders.

PCC is generally considered to show a favorable prognosis ${ }^{3,8}$. In the present case, a short period of topical steroids and emollients was enough to improve the lesion.

To our knowledge, this is the first report of RCM findings in PCC, and these findings helped to differentiate it from $A C$ and early SCC, prior to biopsy. Documentation and reporting of the features of such cases can help the physician determining the preoperative diagnosis in such cases.

\section{References}

1. Solomon LW, Wein RO, Rosenwald I, Laver N: Plasma cell mucositis of the oral cavity: report of a case and review of the literature. Oral Surg Oral Med Oral Pathol Oral Radiol Endod 2008;106:853-60.

2. Puvanendran M, Lieder A, Issing W: Plasma cell mucositis of Oro- and hypopharynx: a case report. Case Rep Otolaryngol 2012;2012:304136.

3. Arun K, Ambooken M, Varghese SS, Varghese T, Mathew TJ: A rare case of plasma cell mucositis in a young patient. J Indian Soc Periodontol 2017;21:63-5

4. Ito T, Natsuga K, Tanimura S, Aoyagi S, Shimizu H: Dermoscopic features of plasma cell cheilitis and actinic cheilitis. Acta Derm Venereol 2014;94:593-4.

5. Lee JY, Kim KH, Hahm JE, et al: Plasma Cell Cheilitis: A Clinicopathological and Immunohistochemical Study of 13 Cases. Ann Dermatol 2017;29:53642.

6. Fujimura $Y$, Natsuga $K$, Abe $R$, Morita $Y$, Nomura $T$, Shimizu $H$ : Plasma cell cheilitis extending beyond vermillion border. J Dermatol 2015;42:935-6.

7. Zoon JJ: Balanoposthite chronique circonscrite bénigne à plasmocytes. Dermatologica 1952;105:1-7.

8. White JW Jr, Olsen KD, Banks PM: Plasma cell orificial mucositis. Report of a case and review of the literature. Arch Dermatol 1986;122:1321-4.

9. Arun K, Ambooken M, Varghese SS, Varghese T, Mathew JJ: A rare case of plasma cell mucositis in a young patient. I Indian Soc Periodontol 2017;21:63-5.

10. Lupu M, Caruntu A, Caruntu C, et al: Non-invasive imaging of actinic cheilitis and squamous cell carcinoma of the lip. Mol Clin Oncol 2018;8:640-6.

11. Benati E, Pampena R, Bombonato C, Borsari S, Lombardi M, Longo C: Dermoscopy and reflectance confocal microscopy for monitoring the treatment of actinic cheilitis with ingenol mebutate gel: Report of three cases. Dermatol Ther 2018;31:e12613.

12. Güleç AT: Diagnosing squamous cell carcinoma of the lip using dermoscopy. J Am Acad Dermatol 2017;76:S82-3.

13. Benati $E$, Persechino F, Piana $S$, et al: Dermoscopic features of squamous cell carcinoma on the lips. Br J Dermatol 2017;177:e41-3.

14. Ulrich M, González S, Lange-Asschenfeldt B, et al: Non-invasive diagnosis and monitoring of actinic cheilitis with reflectance confocal microscopy. J Eur Acad Dermatol Venereol 2011;25:276-84

15. Rishpon A, Kim N, Scope A, et al: Reflectance confocal microscopy criteria for squamous cell carcinomas and actinic keratoses. Arch Dermatol 2009;145:766-72. 